\title{
Long-Term Variations of Aerosols Concentration over Ten Populated Cities in Iran based on Satellite Data \\ Foroozan Arkian*
}

Meteorology Department, Marine Science and Technology Faculty, North Tehran Branch, Islamic Azad University, Tehran, Iran

\begin{abstract}
In this study, three different sensors of satellites including the Moderate Resolution Imaging Spectroradiometer (MODIS), Multi-angle Imaging Spectroradiometer (MISR), and Total Ozone Mapping Spectrometer (TOMS) were used to study spatial and temporal variations of aerosols over ten populated cities in Iran. Also, the Hybrid Single Particle Lagrangian Integrated Trajectory (HYSPLIT) model was used for analyzing the origins of air masses and their trajectory in the area. An increasing trend in Aerosol concentration was observed in the most studied cities in Iran during 1979-2016. The cities in western part of Iran had the highest annual mean of aerosol concentration. The highest AOD value $(0.76 \pm 0.51)$ was recorded in May 2012 over Ahvaz, and lowest value $(0.035 \pm 0.27)$ was recorded in December 2013 over Tabriz. After Ahvaz, the highest AOD value was found over Tehran (annual mean: $0.11 \pm 0.20$ ). The results show that AOD increases with increasing industrial activities, but the increased frequency of aerosols due to land degradation and desertification is more powerful in Iran. The trajectories analysis by the HYSPLIT model showed that the air masses come from Egypt, Syria, and Lebanon, and passed over the Iraq and then reached to Iran during summer. Aerosol Radiative Forcing (ARF) has been analyzed for Zanjan (AERONET site) during 2010-2013. The ARF at surface and top of the atmosphere were found to be ranging from $-79 \mathrm{wm}^{-2}$ to -10 $\mathrm{Wm}^{-2}$ (average: $-33.45 \mathrm{Wm}^{-2}$ ) and $-25 \mathrm{wm}^{-2}$ to $6 \mathrm{wm}^{-2}$ (average: $-12.80 \mathrm{Wm}^{-2}$ ), respectively.
\end{abstract}

Keywords: Aerosol optical depth; MODIS; MISR; TOMS; AERONET; HYSPLIT; Iran

\section{Introduction}

Aerosol Optical Depth (AOD) is an integral measure of the total amount of aerosols contained within a vertical column of air. Atmospheric aerosols are a complex mixture of particulate matter (PM) and liquid/solid particles suspended in the atmosphere. These particles include a combination of organic compounds, inorganic ions, crustal compounds, the biological substance and several trace elements. The diameter of the aerosols varies from nanometres to hundred micrometres, depending on formation mechanisms, the sources, and the meteorological and geographical situations. De Miranda et al. has studied on the relationship between aerosol particles chemical composition and optical properties to identify the biomass burning contribution to fine particles concentration in Brazil. Kosmopoulos et al. [1-4] indicated that aerosols have been a main factor in the global climate change of the last two decades because they play an important role in radiative transfer and the radiative balance of the atmosphereearth system. Some satellite remote sensing studies have served to monitor the radiative effects of aerosols and the global aerosol budget, as well as their impact on climate [5-8]. Researchers have also used AERONET (Aerosol Robotic Network) remote sensing to show the optical properties of each aerosol type [9-14].

There have been comparatively few studies on aerosols in Iran based solely on ground data [15-17]. Masoumi et al. [15] used ground-based aerosol monitoring network to study optical properties of aerosols such as AOD, AVSD, AE, SSA and refractive index over Zanjan during 20062008. Bayat et al. [16] analyzed SSA and the polarized phase function of atmospheric aerosols over Zanjan during 2010-2012. Khoshsima et al. [17] investigated AOD, AE and Angstrom turbidity coefficient during 2009-2010 over Zanjan. Also, a few studies have been conducted based on satellite data [18,19]. Rashki et al. [18] studied on seasonal cycle MISR, MODIS and TOMS AOD over Sistan region in Iran. The results show high aerosol concentration during summer and lower in winter. The Aerosol Index and AOD highlighted the Sistan region as a major source of dust in southwest Asia. Gharibzadeh et al. [19] studied optical properties and radiative effect of aerosol during two dust events in 2013 over Zanjan.

Aerosols concentration is growing in most of the Middle East due to increasing population and industrialization adjacent to megacities. In this research, we have investigated the spatial and temporal variation of aerosol optical depth over ten populated cities in Iran using the Imaging Spectroradiometer (MODIS), the Multi-angle Imaging Spectroradiometer (MISR), and the Total Ozone Mapping Spectrometer (TOMS). AOD retrievals of MISR and MODIS are validated by ground base AERONET data (Zanjan city site). In addition, The NOAA Hybrid Single Particle Lagrangian Integrated Trajectory (HYSPLIT) model was used to identify the origin and track of dusty air masses to Iran during summer. In addition, we have analyzed Aerosol Radiative Forcing (ARF) at the earth surface and the top of the atmosphere over Zanjan during 2010-2013.

\section{Methodology}

\section{Studied area}

Iran has a varied diversity of natural resources. The Zagros mountains cover the northwestern and central parts of Iran; the Alborz mountains cover the northern and western parts of Iran, and The Great Salt and Emptiness Deserts (The Dasht-e Lut and the Dasht-e Kavir)

*Corresponding author: Arkian F, Meteorology Department, Marine Science and Technology Faculty, North Tehran Branch, Islamic Azad University, Tehran, Iran, Tel: +989125805886; E-mail: f.arkian@gmail.com

Received May 09, 2017; Accepted May 15, 2017; Published May 22, 2017

Citation: Arkian F (2017) Long-Term Variations of Aerosols Concentration over Ten Populated Cities in Iran based on Satellite Data. Hydrol Current Res 8: 274. doi: 10.4172/2157-7587.1000274

Copyright: () 2017 Arkian F. This is an open-access article distributed under the terms of the Creative Commons Attribution License, which permits unrestricted use, distribution, and reproduction in any medium, provided the original author and source are credited. 
are located in central and eastern sections. The Caspian Sea is located in the north, and the Persian Gulf and Oman Sea are located in south Iran. The topographic diversity in Iran makes it unique for any study of spatio-temporal patterns. Iran has a continental type of climate, with cold winters and hot summers. Figure 1 shows average monthly temperature and rainfall from 1960-1990 at Tehran. The ten largest and most populated cities have been selected for analysis of the spatial and temporal variations in aerosol concentrations in Iran (Figure 2).

\section{Dataset and analysis}

Aerosol properties from three datasets including TOMS, MODIS and MISR sensors were used to understand and analyze the variability of aerosols over different regions of Iran. Table 1 shows satellite and AERONET datasets used in this study.

Aerosol optical depth is an integral measure of the total amount of aerosol contained within a vertical column of air. Thus, it collectively assesses such aerosols as haze, desert dust, sea salt and smoke particles. The sun photometer measure AOD by a voltage $(\mathrm{V})$ that is related to the irradiance (I). The irradiance and sun photometer voltage at the top of the atmosphere are Io and Vo, respectively. The Beer-Lambert-Bouguer law is used to determine total optical depth $\left(\tau_{\text {тот }}\right)$ :

$$
\mathrm{V}(\lambda)=\mathrm{Vo}(\lambda) \mathrm{d}^{2} \exp \left[-\tau(\lambda)_{\text {TOT }}{ }^{*} \mathrm{~m}\right]
$$

Where $\mathrm{V}$ is voltage (at wavelength $\lambda$ ), $\tau_{\text {Tот }}$ is the total optical depth and $d$ is the actual average of Earth-Sun distance, and $m$ is the optical air mass [20].

Aerosol Robotic Network (AERONET): This study uses aerosol optical depth (AOD) data from AERONET (Aerosol Robotic NETwork). AERONET is a network of surface monitoring stations, each of which uses the identical automatic Sun-sky scanning spectral radiometer [20]. AERONET provides and archives two kinds of measurements that are useful in assessing aerosols characteristics. One is direct sun radiation extinction across the spectrum and the second is the angular distribution of sky radiance. From this, it is possible to compute in near-real-time aerosol spectral optical depths, aerosol size distributions, etc. There is only one AERONET monitoring station in Iran, in Zanjan city (IASBS), and we have used its AOD, AVSD, AE, SSA, ASY and ARF data in this research.

Total Ozone Mapping Spectrometer (TOMS): We have used TOMS to measure the amount of aerosols suspended in the atmosphere. Three type of TOMS including TOMS Nimbus 7 data (1979-1993), TOMS EP data (1996-2005) and OMTO3d data (2006-2016) were used to identify spatial and temporal variation of the Aerosol Index (AI) during 36 years. For TOMS, AI is defined as

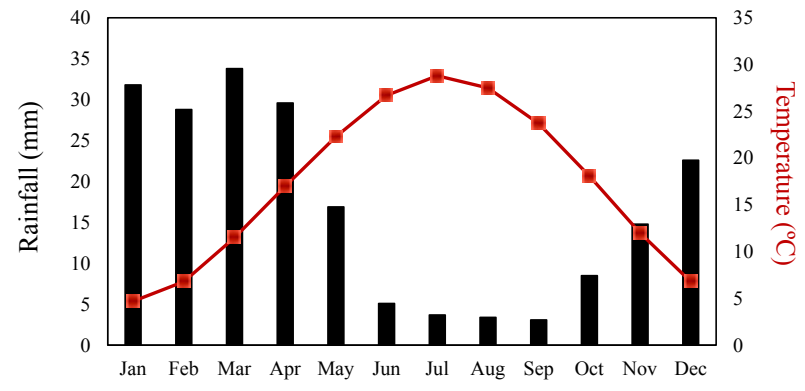

Figure 1: Average monthly temperature and rainfall in Tehran from 1960-1990.

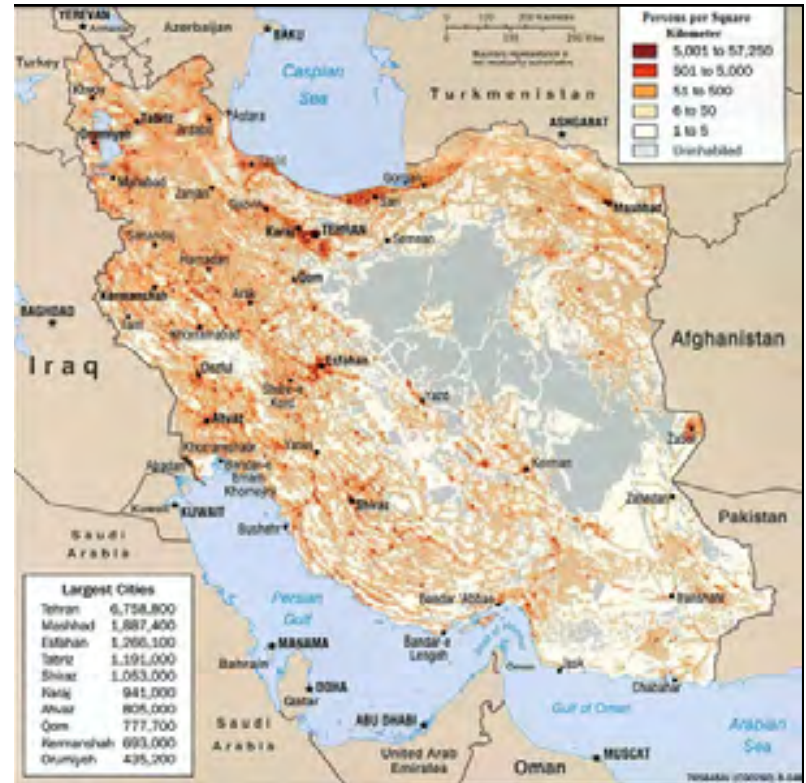

Figure 2: Map of study area. Cities evaluated and their population are indicated in the inset.

$$
\mathrm{AI}=-100\left\{\log 10\left(\frac{\mathrm{I}_{331}}{\mathrm{I}_{360}}\right)_{\text {measured }}-\log 10\left(\frac{\mathrm{I}_{331}}{\mathrm{I}_{360}}\right)_{\text {calculated }}\right\}
$$

where $\mathrm{I}_{331}$ and $\mathrm{I}_{360}$ are, TOMS measured and calculated reflectances at $331 \mathrm{~nm}$ and $360 \mathrm{~nm}$ (using the Lambertian Equivalent Reflectivity derived at $360 \mathrm{~nm}$ ).

Moderate Resolution Imaging Spectroradiometer (MODIS): The MODIS instrument mounted on the Terra and the Aqua satellites have the spectral bands ranging in wavelength from $250 \mathrm{~m}$ to $1.0 \mathrm{~km}$ at the nadir and various spatial resolutions. MODIS monitors the AOD with an error of $0.03 \pm 0.05 \mathrm{AOD}$ over the ocean and $\pm 0.05+0.15 \mathrm{AOD}$ over land. In this study is based on Deep Blue AOD at $550 \mathrm{~nm}$ (MYD08_D3) for MODIS with spectral resolution from 0.415 to 14.235 micron.

Multi-angle Imaging Spectro Radiometer (MISR): The MISR instrument installed on the Terra satellite collects observations at nine different viewing angles. MISR enables to identify different types of atmospheric particles [21], cloud forms, and land surface covers in a sun-synchronous orbit. Kahn et al. [22] mentioned that $70 \%$ of MISR AOD data are within 0.05 (or $20 \% \times$ AOD) of sun-photometermeasured AOD values.

We have used the MISR Level 3 Component Global Aerosol Product (MIL3MAE_v4 AOD) covering a day and month of column aerosol 555 nanometer optical depth. This data product is a global summary of the Level 2 aerosol parameters of interest averaged over a month, with a resolution of 0.5 degree by 0.5 degree. Aerosol Robotic Network (AERONET) data for the Zanjan station is also considered to verify MISR $_{\mathrm{AOD}}$ data.

\section{Results and Discussion}

\section{Annual trend in TOMS Aerosol Index (AI)}

Monitoring of AI trends by TOMS has the advantage of global coverage and applies the same approach to detecting aerosol trends over different sites. An increasing trend in AI can be observed in most selected cities during 1979-2015 (Figure 3). A decreasing trend in 

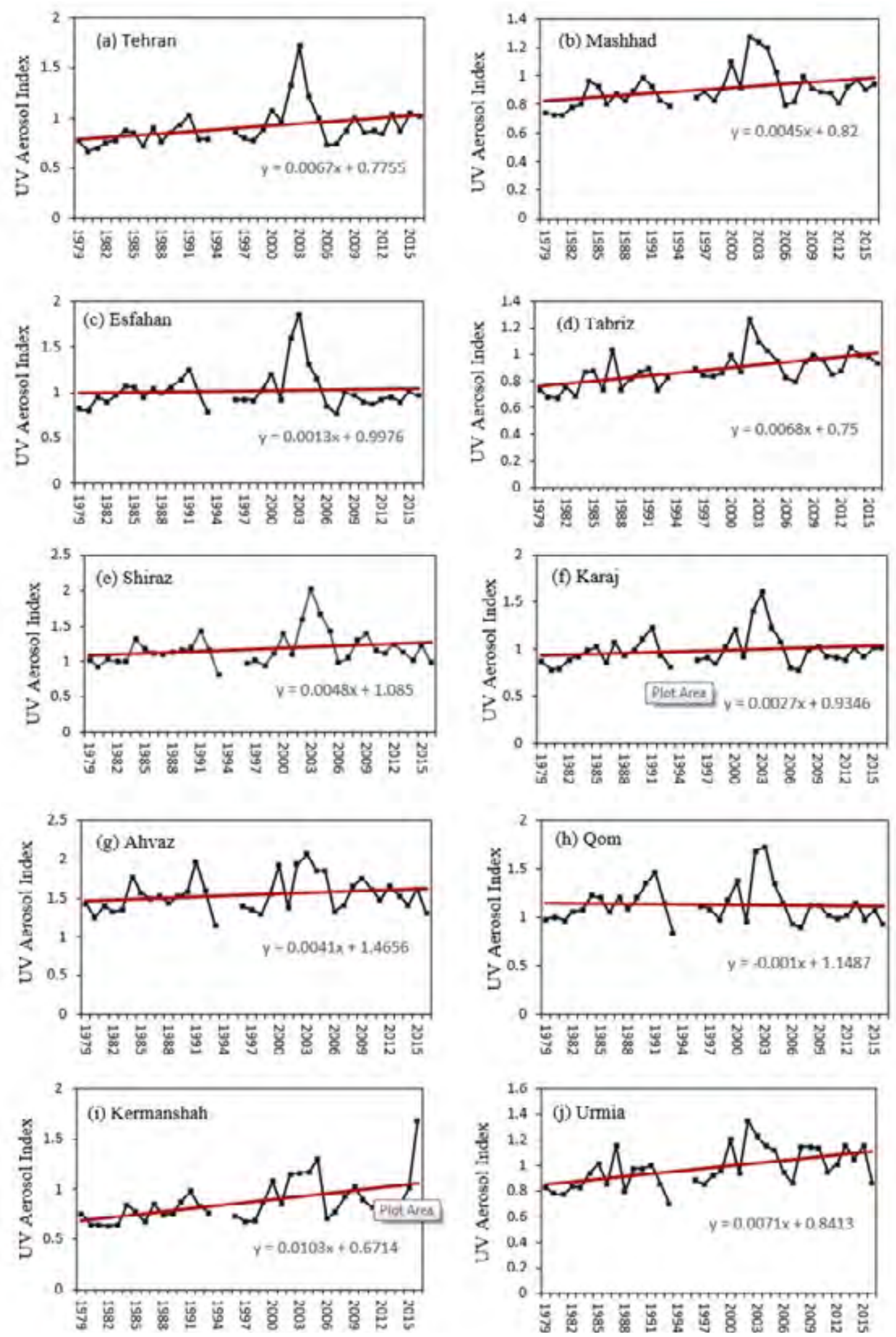

Figure 3: Variation of UV Aerosol Index for the most populated cities in Iran during 1979-2016, using TOMS Nimbus 7 data (1979-1993), TOMS EP data (1996-2005) and OMTO3d data (2006-2016). 


\begin{tabular}{|c|c|c|c|}
\hline Sensor & Data used & Product & Special resolution \\
\hline TOMS Nimbus-7 & $01 / 1 / 1979-31 / 12 / 1992$ & Daily level & $1 \times 1.25^{\circ}$ \\
\hline TOMS EP & $22 / 07 / 1996-31 / 12 / 2005$ & Daily level & $1 \times 1.25^{\circ}$ \\
\hline TOMS OMI & $01 / 01 / 2005-07 / 05 / 2016$ & Daily level & $340-380$ \\
\hline MISR Terra & $2000-2015$ & Daily level 3 & $340-380$ \\
\hline MODIS Terra & $2000-2015$ & Daily level 2 & $0.5 \times 0.5^{\circ}$ \\
\cline { 2 - 4 } & $2010-2013$ (Plots) & Daily level 2 & $1^{\circ}$ \\
\hline AERONET (Ground base data) & 2010 & 550 & \\
\hline
\end{tabular}

Table 1: Satellite and AERONET datasets used in this study.

AI can be observed just at Qom city. The greatest increases in annual mean AOD is seen in Kermanshah, Urmia and Tabriz, respectively. The increase in anthropogenic aerosol emissions is a result of increasing populations, growing industrialization, and urbanization. Other studies show the high level of anthropogenic aerosol emissions over megacities close to the study area by satellite monitoring [23]. On the other hand, Iran is located in the center of the Northern Hemisphere dust belt. Observed rising trends in most of cities also can be related to the recent increase in the frequency of dust events in Iraq due to land desertification [24]. The Khuzestan Plain in southwest of Iran is the area with the highest frequency of dust events, over which dusty air is almost permanently present in summer, while the coastal plain of the Persian Gulf is the second most affected area [25]. The satellite cannot distinguish differences between natural and anthropogenic aerosol due to the mixing process in atmosphere. But since the long-term changes in natural aerosols are relatively small, the observed increasing and declining trends can be attributed to changes in anthropogenic aerosols. The extreme value in AI is seen during 2003 in most cities of Iran. A lot of dust storms were blowing over Iran in March, May, November, and December during 2003. The MODIS sensor with the maximum spatial resolution of $250 \mathrm{~m}$ shows a dust storm over Iran, Saudi Arabia, Iraq, United Arab Emirates, and Kuwait on $28^{\text {th }}$ May 2003 (Figure 4a). The dust is thicker over the Persian Gulf. The time averaged map of daily AI shows that the origin of the dust storm is from the eastern part of Saudi Arabia and United Arab Emirates (Figure 4b).

\section{Annual trend in MISR aerosol optical depth}

The MISR views the whole Earth's surface every nine days. Depending on latitude, repeat coverage occurs between 2 and 9 days. MISR has a $\sim 400 \mathrm{~km}$ swath (MISR Technical Document). To confirm the conclusions from TOMS data, we have analyzed MISR AOD data. Similar increasing trends in aerosol concentrations over the ten Iranian cities have been detected from MISR data over the period 2000-2015 (Figure 5). Tehran and Karaj very similar variation in AOD because they are geographically close. The annual mean and rising trend of AOD in Ahvaz (capital of Khuzestan province and $7^{\text {th }}$ populated city) are higher than in other cities. The MISR $_{\text {AOD }}$ slightly showed high dust amount in

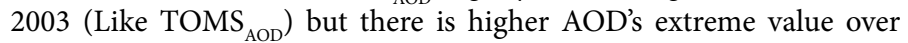
western cities of Iran including Ahvaz, Kermanshah, Urmia, Tabriz, and Shiraz in 2008. Other research showed the same result in increasing dust storm events over the study area in 2008 [25,26]. Iran experienced the worst dust storm of the last decade in July 2008. The storm formed over Iraq and then spread eastward to Iran and covered the western and northern part of Iran and the northern part of Saudi Arabia as well. The satellite image of absorption optical depth shows that the thickness of the dust is enough to completely obscure the underlying surface of the eastern part of Iraq and western part of Iran (Figure 6a). Solid or liquid particles suspended in the air can absorb or reflect sunlight before it reaches the Earth's surface. The Ozone Monitoring Instrument (OMI) observed aerosols over Iran, Iraq, and the Saudi Arabia on July 5, 2008 (Figure 6b).
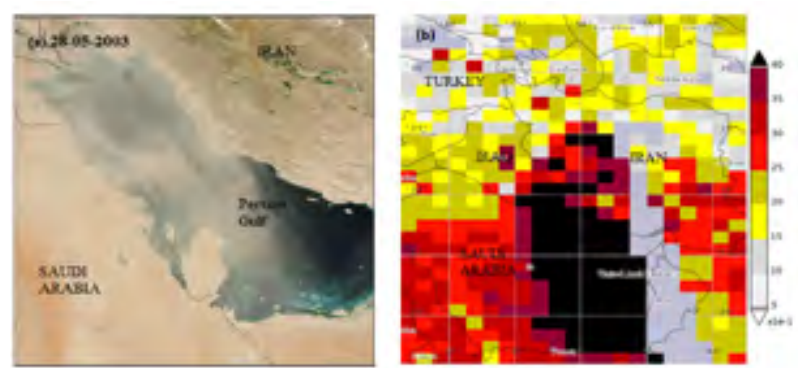

Figure 4: The dust storm event over Iran, Saudi Arabia, Iraq, United Arab Emirates and Kuwait on $28^{\text {th }}$ May 2003 (a) MODIS image (b) Time averaged map of daily Aerosol Index (TOMS).

\section{Annual means and seasonal variations in MODIS AOD}

Table 2 shows seasonal and annual values of AOD using MODIS data over Iran. Data were extracted using $550 \mathrm{~nm}$ and were analyzed for years 2000-2015. The highest values of AOD were observed in Ahvaz in the southwestern part of Iran. The annual mean AOD for Ahvaz was $0.39 \pm 0.25$ over this period. The drying of Hor al-Azim, one of the most important wetlands in southwestern Iran, is probably the primary reason for high concentration of aerosols in this city. After the war with Iraq, oil extraction around the wetland decreased the water level and increased the frequency of dust storms in the Khuzestan. The second reason is that some dust sources in the Middle East such as Iraq, Syria and Arabian Peninsula contribute to dust production in the area. The wind direction in the warm/dry months can transport the dust from these regions to the western part of Iran [27]. The number of dust storms striking western Iran increased markedly between 2000 and 2009 by as much as 70 to 175 percent [28]. After Ahvaz, the highest AOD values are at Tehran (Table 2). This result probably is due to high industrial activities and urbanization in this Mega-city. The results show that AOD increases with increasing industrial activities, but the increased frequency of aerosols due to land degradation and desertification is more powerful in Iran. The highest mean AODs were recorded during the spring and the lowest AODs in the autumn for most of the cities (Table 2).

Figure 7 confirms that AOD values are higher over Ahvaz. The highest AOD value $(0.76 \pm 0.51)$ was found in May 2012 over Ahvaz and, the lowest AOD value $(0.035 \pm 0.27)$ was found in December 2013 over Tabriz. Seasonal AOD variations can be found in the all cities with the highest values in spring and summer; and the lowest values in winter (Figure 7). High wind speeds mobilizing greater quantities of dust in the area during warm months and picks up the dust. In addition, the lowest AOD value might be due to precipitation in the cold season [29]. Kim et al. [30] found that AOD is high in March (0.44 \pm 0.25$)$ and low in September $(0.24 \pm 0.21)$ in the East Asian region in 2009 . 


\begin{tabular}{|c|c|c|c|c|c|c|}
\hline \multirow{2}{*}{ City name } & \multirow{2}{*}{ Population } & \multicolumn{5}{|c|}{ Annual and seasonal mean and standard deviation of AOD at $550 \mathrm{~nm}$} \\
\hline & & Annual mean & Winter & Spring & Summer & Autumn \\
\hline Tehran & $67,58,800$ & $0.11 \pm 0.2051$ & $0.11 \pm 0.0132$ & $0.15 \pm 0.0783$ & $0.11 \pm 0.2472$ & $0.09 \pm 0.1132$ \\
\hline Mashhad & $18,87,400$ & $0.08 \pm 0.2823$ & $0.07 \pm 0.0167$ & $0.08 \pm 0.0531$ & $0.08 \pm 0.2408$ & $0.08 \pm 0.1673$ \\
\hline Esfahan & $12,66,100$ & $0.10 \pm 0.2342$ & $0.12 \pm 0.0283$ & $0.16 \pm 0.0209$ & $0.07 \pm 0.1056$ & $0.07 \pm 0.01481$ \\
\hline Tabriz & $11,91,000$ & $0.07 \pm 0.2131$ & $0.09 \pm 0.0821$ & $0.09 \pm 0.1064$ & $0.06 \pm 0.3925$ & $0.06 \pm 0.1222$ \\
\hline Shiraz & $10,53,000$ & $0.08 \pm 0.1761$ & $0.09 \pm 0.1256$ & $0.10 \pm 0.0423$ & $0.07 \pm 0.1802$ & $0.07 \pm 0.1516$ \\
\hline Karaj & $9,41,000$ & $0.10 \pm 0.1439$ & $0.07 \pm 0.0253$ & $0.13 \pm 0.0687$ & $0.11 \pm 0.0470$ & $0.07 \pm 0.1811$ \\
\hline Ahvaz & $8,05,000$ & $0.39 \pm 0.2497$ & $0.31 \pm 0.1536$ & $0.48 \pm 0.2436$ & $0.50 \pm 0.0631$ & $0.29 \pm 0.0483$ \\
\hline Qom & $7,77,700$ & $0.10 \pm 0.1015$ & $0.09 \pm 0.0349$ & $0.14 \pm 0.0205$ & $0.10 \pm 0.0202$ & $0.08 \pm 0.0704$ \\
\hline Kermanshah & $6,93,000$ & $0.08 \pm 0.2331$ & $0.11 \pm 0.1541$ & $0.09 \pm 0.0580$ & $0.08 \pm 0.2504$ & $0.06 \pm 0.1534$ \\
\hline Urmia & $4,35,200$ & $0.09 \pm 0.2514$ & $0.09 \pm 0.0361$ & $0.10 \pm 0.0821$ & $0.07 \pm 0.2236$ & $0.09 \pm 0.1758$ \\
\hline
\end{tabular}

Table 2: Annual and seasonal means of AOD at $550 \mathrm{~nm}$ in different cities of Iran for the period 2000-2015.

\section{Comparison of MODIS ${ }_{\mathrm{AOD}}$ and $\mathrm{MISR}_{\mathrm{AOD}}$ and $\mathrm{AERONET}_{\mathrm{AOD}}$ data}

Intercomparison is necessary to evaluate the accuracy of a longterm database for climatological studies. In this study, the area average AOD correlation between MODIS and MISR over Iran is calculated. The correlation has been examined using the daily average of MISR (MIL3DAE v4) and Level-3 MODIS (MOD08_D3.v6) and data gotten from the GIOVANNI site. The two datasets have the different spatial resolution. The MODIS data are available with $1 \times 1{ }^{\circ}$ whereas MISR data are available at $0.5 \times 0.5^{\circ}$. MISR were converted to spatial resolution $1 \times$ $1^{\circ}$ using a box averaging algorithm in the Giovanni site.

The correlation between MODIS and MISR AOD data was about 0.7 in winter, spring and autumn seasons of 2010 (Figure $8 \mathrm{a}, 8 \mathrm{~b}$ and $8 \mathrm{~d}$ ). The correlation coefficient was calculated to be 0.36 for summer of 2010 (Figure 8c). The same studies were conducted in Southeastern Asia [31] and Pakistan [32,33], and they found high correlation coefficients $(\geq 0.7)$ between MODIS and MISR AOD. The spatial map correlation between MODIS and MISR AOD data showed low correlation over Alborz and Zagros Mountains range in Iran (not shown). This result could be a result of insufficient data points in the region due to snow cover in high elevation of the mountains range. We extracted the AOD data of the sun photometer site (IASBS) for 2010 from the AERONET level 2 data archive and then we used it for assessing the accuracy of MISR $_{\mathrm{AOD}}$ and MODIS $_{\mathrm{AOD}}$ data. This sun photometer site is located in Zanjan city in Northwest Iran. Since, the MISR observation repeat time is only 3 or 4 visits per month for the IASBS site, we compare AERONETAOD and MISRAOD daily data when MISR swept this site. Validation of MISR ${ }_{\mathrm{AOD}}$ and MODIS $_{\mathrm{AOD}}$ using $\mathrm{AERONET}_{\mathrm{AOD}}$ shows a high correlation coefficient of 0.87 and 0.76 at the 0.05 significance level, respectively.

\section{Air mass trajectory analysis}

To better understand the origins of the air masses arriving in Iran from dust sources during warm and cold months, we did back trajectory analyses using HYSPLIT model [34]. These back trajectories were analyzed for seven days at four altitudes $(3003 \mathrm{~m}, 2000 \mathrm{~m}, 1000 \mathrm{~m}$, and $500 \mathrm{~m}$ ). The paths of air masses that reached Ahvaz and Tehran cities in 10 May and 10 Jun 2011 are shown in Figure 9. The trajectories show that air masses come from Syria, Lebanon, and passed over the Iraq and then reached to Ahvaz during 10 May 2011 (Figure 9a). On 10 Jun 2011, the air masses reached Tehran from Egypt, Lebanon, and then Syria and Iraq (Figure 9b). The air masses in summer reach to Iran from dry deserts in the north of Africa such as the Sahara. In addition, some dust sources in the Middle East including Syria and Iraq increase in the aerosol concentrations over Iran. In winter, the air masses propagate from Europe and Mediterranean Sea regions (Not shown) and cause a lot of rainfall over Iran.

\section{Aerosol radiative forcing}

Solar radiation as the main forcing of atmospheric circulation controls the weather and climate system. Atmospheric aerosols can cause a decrease in solar radiation flux by radiative effects. Ramaswamy et al. [35] defined Aerosol Radiative forcing (ARF, in $\mathrm{wm}^{-2}$ ) as the net imbalance in irradiance (Solar plus long wave) and can be shown as following equation:

$$
\Delta \mathrm{F}=\left(\mathrm{F}_{\mathrm{a}} \uparrow-\mathrm{F}_{\mathrm{a}} \downarrow\right)_{\text {with }}-\left(\mathrm{F}_{0} \uparrow-\mathrm{F}_{0} \downarrow\right)_{\text {without }}
$$

Where $\Delta \mathrm{F}$ is irradiance, the first and second sentences in the right of the equation are the net irradiance with and without aerosol, respectively. Indirectly, these changes effect on specific ARF changes. Figure 10 shows the variation of ARF at the earth's surface (BOA) and top of atmosphere (TOA) also, Aerosol Optical Depth (AOT) at Zanjan during the 2010-2013 period. Seasonal ARF variations was found over Zanjan with the highest values in warm seasons and the lowest values in cold seasons (Figure 10). The deep cooling effect has been occurred on May 2011 due to mineral dust's effect of reflecting and cooling at the visible wavelengths. However, Dust's warming counters half of its cooling effect due to absorbing and warming at the longer infrared wavelengths [36]. The ARF at surface and TOA were found to be ranging from $-79 \mathrm{Wm}^{-2}$ to $-10 \mathrm{Wm}^{-2}$ (average: $-33.45 \mathrm{Wm}^{-2}$ ) and $-25 \mathrm{wm}^{-2}$ to 6 $\mathrm{wm}^{-2}$ (average: $-12.80 \mathrm{Wm}^{-2}$ ), respectively. The difference between ARF at surface and TOA is higher in Jun than other months. Radiative forcing at the BOA is much larger ( 3 times) than that at the TOA. An increase in AOT would lead to the decrease in radiative forcing (more negative value) at the surface and top of the atmosphere. The negative values of ARF indicate solar radiative cooling effect and positive values of ARF indicate radiative warming effect [37]. Strong correlation between ARF and Aerosol Optical Thickness was calculated -0.92 at 0.05 significance level.

\section{Conclusion}

Three satellite sensors MODIS, TOMS and MISR have been used to study the seasonal and annual variability of aerosols concentration over the ten populated cities in Iran. Both TOMS and MISR data showed an increase in aerosols concentration in most cities with time. The maximum AOD value $(0.76 \pm 0.51)$ was found in May 2012 over Ahvaz city in southwestern Iran. Also, the highest annual AOD means were found over Ahvaz by $0.39 \pm 0.24$. The cities in the western part of Iran had highest annual means of aerosol concentration during 1979-2016. Since the western part of Iran does not include the biggest and most populated cities, it can be concluded that the highest value of aerosol concentration in this area is not the result of increasing urbanization and industrialization. The increase in the frequency of dust outbreaks in the Hor al-Azim and some dry areas in Iraq due to 

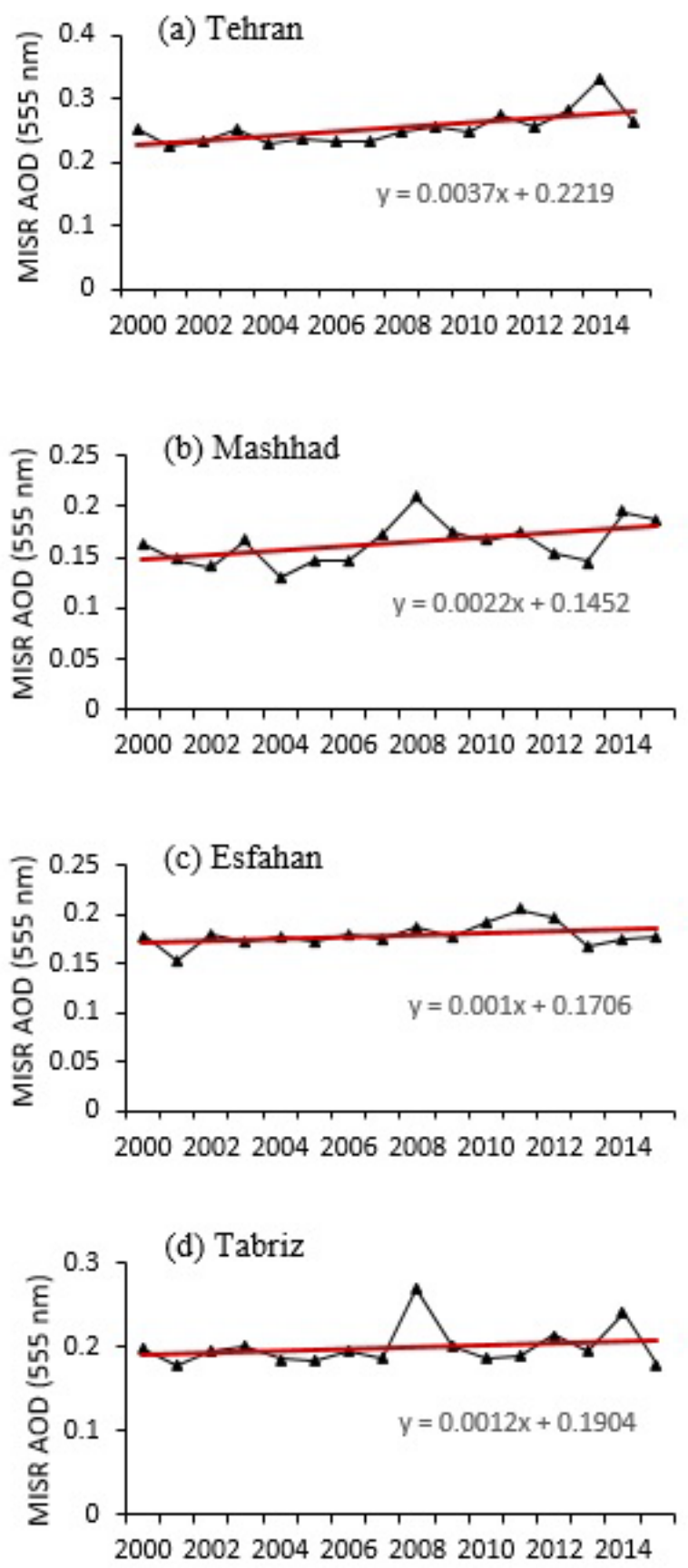

(e) Shiraz

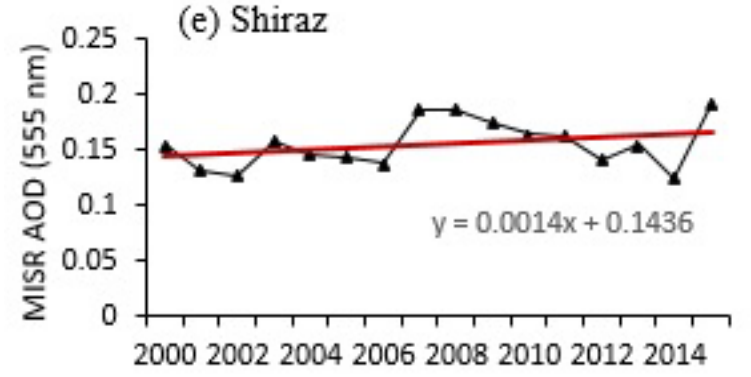

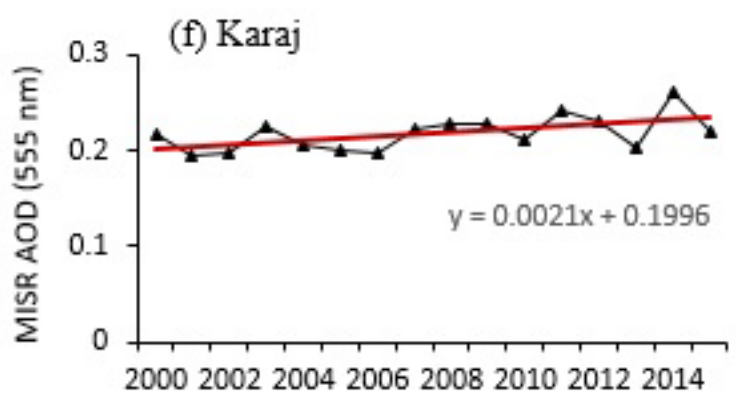
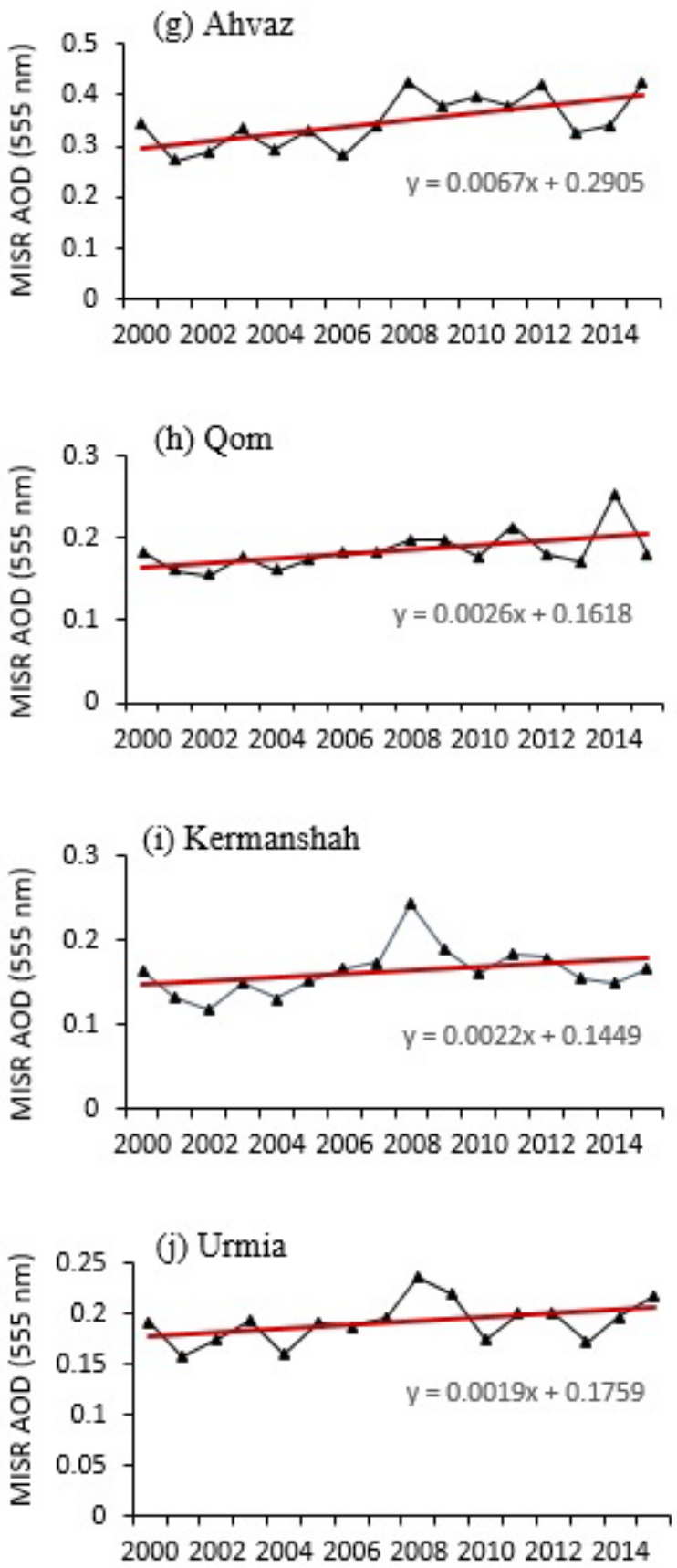

Figure 5: Trends in MISR AOD over selected cities in Iran. 


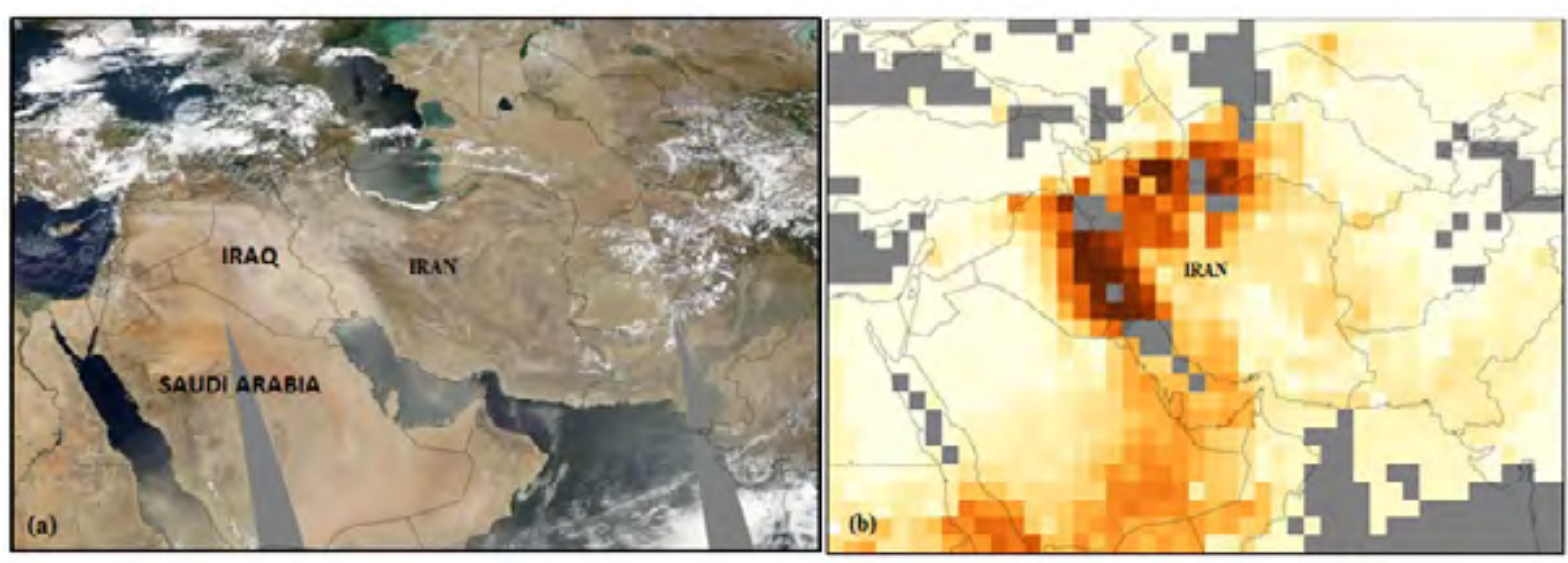

Aerosol Absorption Optical Thickness

0.0

0.225

0.45

Figure 6: The dust storm event over Iran, $5^{\text {th }}$ July 2008 (a) Aqua MODIS image (b) Aerosol Absorption Optical Thickness by Ozone Monitoring Instrument (OMI) on NASA's Aura satellite.

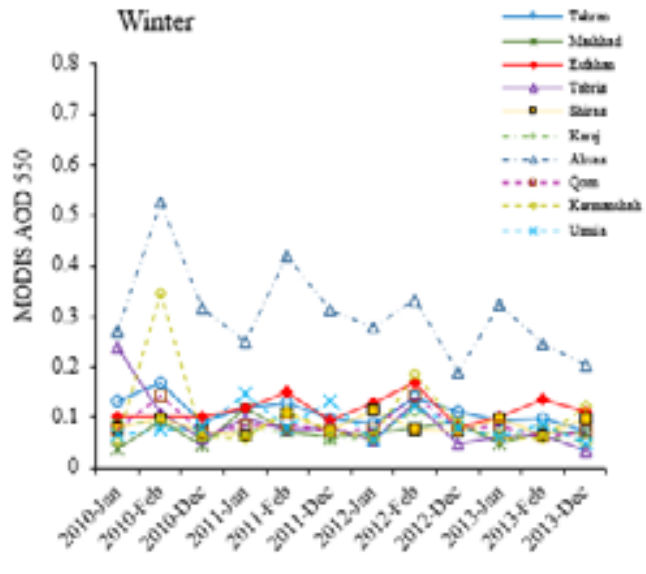

Year-Mouth

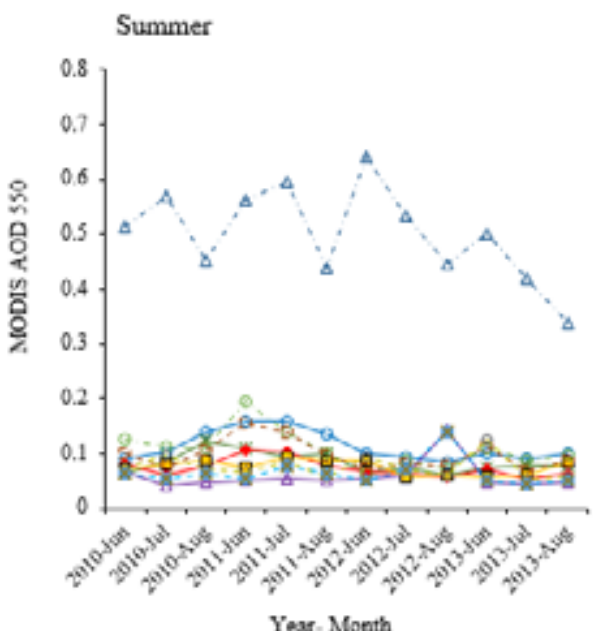

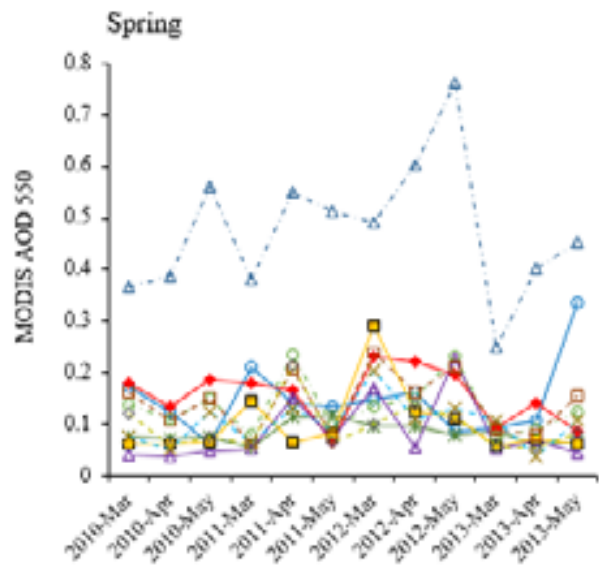

Year-Month

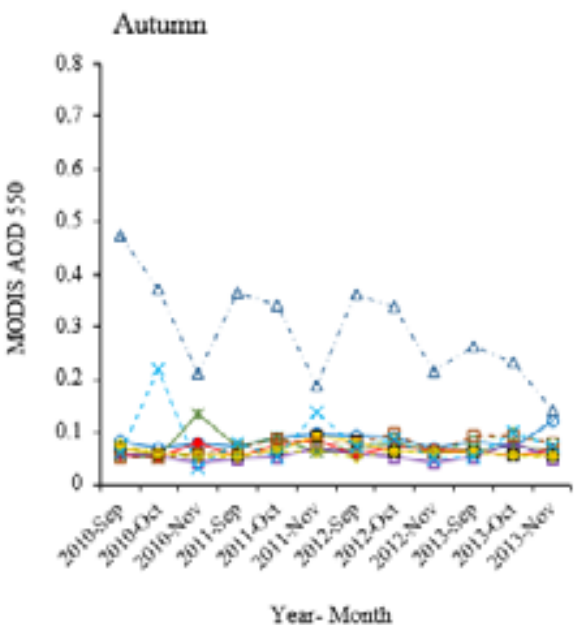

Figure 7: Seasonal variations in MODIS AOD (550 nm) in (a) winter (b) spring (c) summer (d) autumn, for the period covering 2010-2013, over various cities in Iran. 
Citation: Arkian F (2017) Long-Term Variations of Aerosols Concentration over Ten Populated Cities in Iran based on Satellite Data. Hydrol Current Res 8: 274. doi: 10.4172/2157-7587.1000274
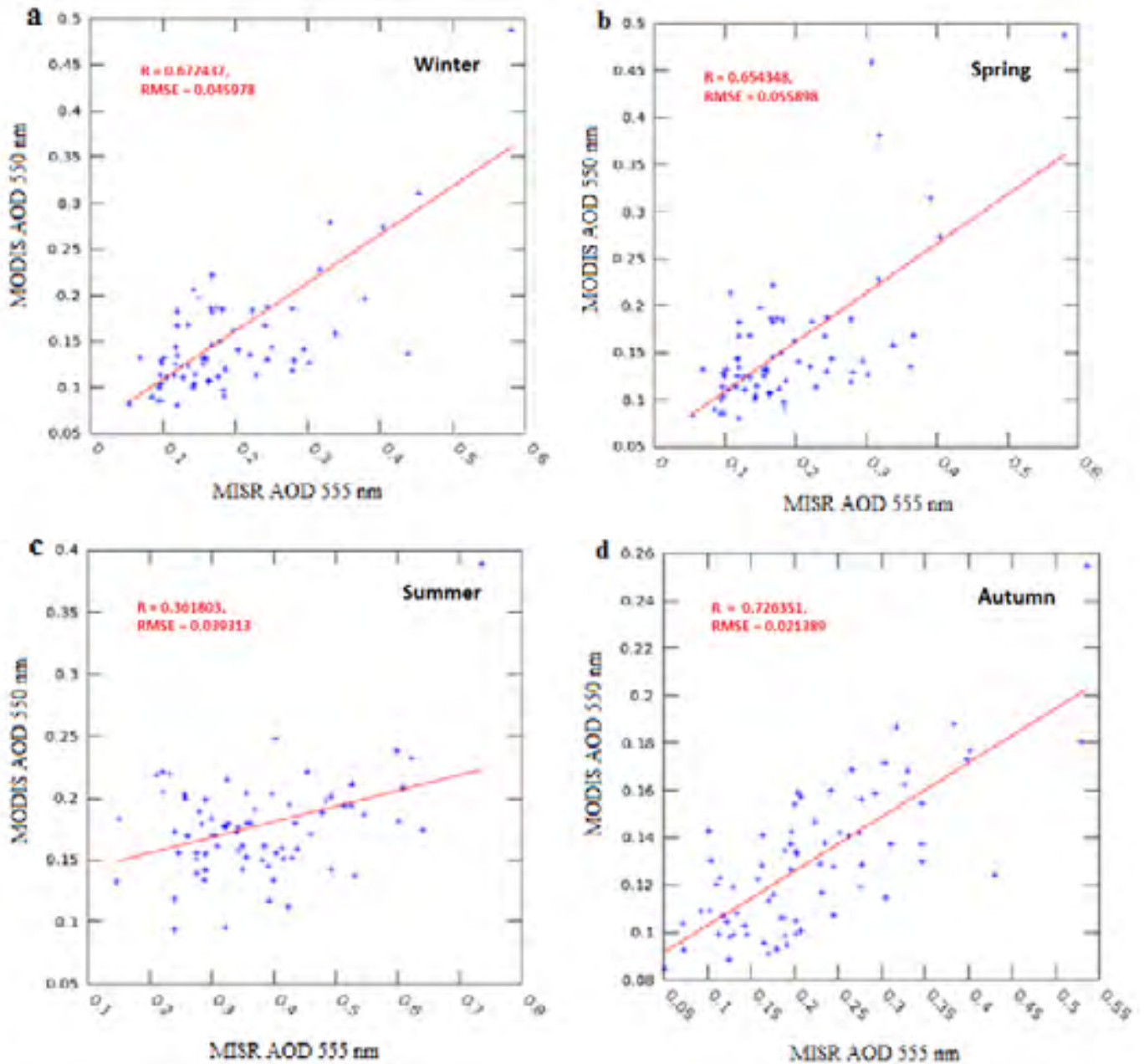

Figure 8: Area average correlations between MODIS and MISR AOD for (a) winter (b) spring (c) summer (d) Autumn over regions of Iran in 2010.

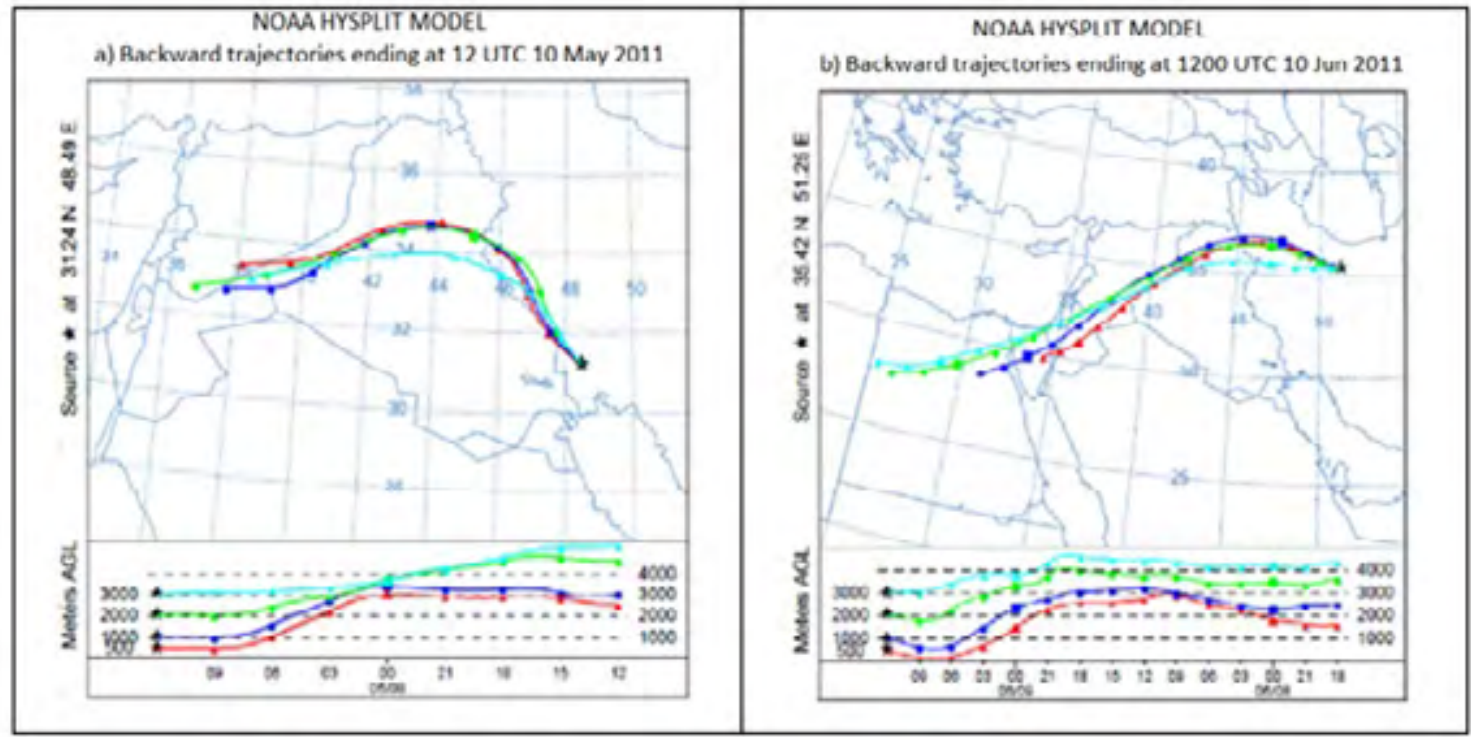

Figure 9: Seven-day back trajectories (a) For Ahvaz city 10 $0^{\text {th }}$ May and (b) For Tehran city $10^{\text {th }}$ June 2011. 
Citation: Arkian F (2017) Long-Term Variations of Aerosols Concentration over Ten Populated Cities in Iran based on Satellite Data. Hydrol Current Res 8: 274. doi: 10.4172/2157-7587.1000274

Page 9 of 10

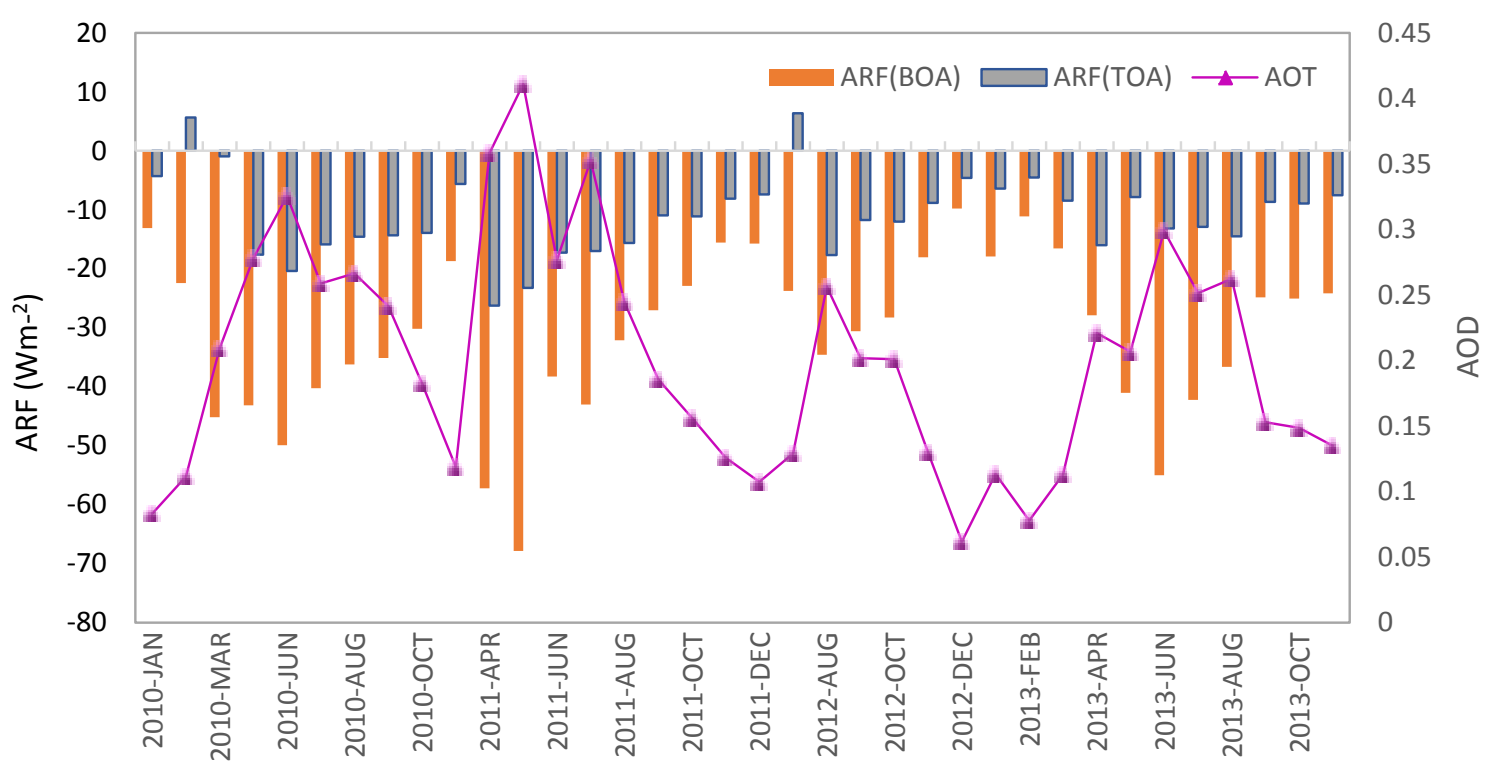

Figure 10: Monthly variation of ARF at earth's surface (BOA) and the top of atmosphere (TOA) during 2010-2013, over Zanjan.

land degradation and desertification are the main factors that affected aerosol concentration in western Iran. According to seasonal analysis, the highest aerosol concentration was found during the spring, and the lowest concentration was found in winter over the selected cities. After Ahvaz, the highest AOD value was found over Tehran (annual mean: $0.11 \pm 0.20$ ). This result probably is due to high industrial activities and urbanization in this city.

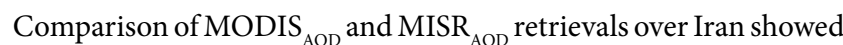
high correlation coefficients $(\geq 0.7)$ in most seasons except summer. The spatial map correlations between MODIS ${ }_{\mathrm{AOD}}$ and MISR $_{\mathrm{AOD}}$ data showed low correlations over Alborz and Zagros Mountains range. Validation of MISR $_{\mathrm{AOD}}$ and MODIS ${ }_{\mathrm{AOD}}$ using AERONET AOD data showed a high correlation coefficient of 0.87 and 0.91 , respectively.

Back trajectory examination of AOD showed that air masses come from Egypt, Syria, Lebanon, and pass over the Iraq and then reach Iran during summer. The air masses in summer reached to Iran from the Sahara Desert in Africa and some dry regions in the Middle East causes the increase in aerosol concentrations over Iran; but in winter, the air masses propagate from Europe and Mediterranean Sea and causes a lot of rainfall over Iran. Aerosol Radiative Forcing (ARF) has been analyzed over Zanjan (AERONET site in Iran) during 2010-2013. The highest values of ARF were observed in warm seasons and the lowest values in cold seasons. The ARF at surface and top of the atmosphere were found to be ranging from $-79 \mathrm{wm}^{-2}$ to $-10 \mathrm{Wm}^{-2}$ and $-25 \mathrm{wm}^{-2}$ to $6 \mathrm{wm}^{-2}$ over Zanjan, respectively. Strong correlation between ARF and Aerosol Optical Thickness was calculated -0.92 at 0.05 significance level $[38,39]$.

\section{Acknowledgements}

We are grateful to Douglas Klotter for his assistance in graphics preparation and data retrieval. Analyses and visualizations used in this study were produced with the Giovanni online data system, developed, and maintained by the NASA GES DISC.

\section{References}

1. Kosmopoulos PG, Kaskaoutis DG, Nastos PT, Kambezidis HD (2008) Seasonal variation of columnar aerosol optical properties over Athens, Greece, based on MODIS data. Remote Sensing of Environment 112: 2354-2366.
2. Papadimas CD, Hatzianastassiou N, Mihaloppoulos N, Kanakidou M, Katsoulis $\mathrm{BD}$, et al. (2008) Assessment of the MODIS collections C005 and C004 aerosol optical depth products over the Mediterranean basin. Atmospheric Chemistry and Physics 9: 2987-2999.

3. Lohmann U, Feichter J (2005) Global indirect aerosol effects: a review. Atmospheric Chemistry and Physics 5: 715-737.

4. Ramanathan V, Crutzen PJ, Kiehl JT, Rosenfeld D (2001) Aerosol, climate, and hydrological cycle. Science 294: 2119-2124.

5. Charlson RJ, Schwartz SE, Hales JH, Cess RD, Coakley Jr JA, et al. (1992) Climate forcing by anthropogenic aerosols. Science 255: 423-430.

6. Tripathi SN, Dey S, Chandel A, Srivastava S, Singh RP, et al. (2005) Comparison of MODIS and AERONET derived aerosol optical depth over the Ganga Basin, India. Annales Geophysicae 23: 1093-1101.

7. Kaufman YJ, Tanre D, Dubovik O, Karnieli A, Remer LA (2001) Absorption of sunlight by dust as inferred from satellite and ground-based remote sensing. Geophysical Research Letter 28: 1479-1482.

8. Kaufman YJ, Tanré D, Boucher O (2002) A satellite view of aerosols in climate system. Nature 419: 215-223.

9. Eck TF, Holben BN, Reid JS, Dubovik O, Smirnov A, et al. (1999) Wavelength dependence of the optical depth of biomass burning, urban, and desert dust aerosols. J Geophys Res 104: 31333-31349.

10. Eck TF, Holben BN, Dubovik O, Smirnov A, Goloub P, et al. (2005) Columnar aerosol optical properties at AERONET sites in central eastern Asia and aerosol transport to the tropical mid-Pacific. J Geophys Res 110: D06202.

11. Holben BN, Tanré D, Smirnov A, Eck TF, Slutsker I, et al. (2001) An emerging ground-based aerosol climatology: Aerosol optical depth from AERONET. J Geophys Res 106: 12067-12097.

12. Dubovik O, King MD (2000) A flexible inversion algorithm for the retrieva of aerosol optical properties from Sun and sky radiance measurements. J Geophys Res 105: 20673-20696.

13. Dubovik O, Holben BN, Eck TF, Smirnov A, Kaufman YJ, et al. (2002) Variability of absorption and optical properties of key aerosol types observed in worldwide locations. J Atmos Sci 59: 590-608.

14. Cattrall C, Reagan J, Thome K, Dubovik O (2005) Variability of aerosol and spectral lidar and backscatter and extinction ratios of key aerosol types derived from selected Aerosol Robotic Network locations. J Geophys Res 110: D10SA11.

15. Masoumi A, Khalesifard HR, Bayat A, Moradhaseli R (2013) Retrieval of aeroso optical and physical properties from ground-based measurements for Zanjan, a city in Northwest Iran. Atmos Res 120-121: 343-355. 
Citation: Arkian F (2017) Long-Term Variations of Aerosols Concentration over Ten Populated Cities in Iran based on Satellite Data. Hydrol Current Res 8: 274. doi: 10.4172/2157-7587.1000274

16. Bayat A, Khalesifard HR, Masoumi A (2013) Retrieval of aerosol singlescattering albedo and polarized phase function from polarized sun-photometer measurements for Zanjan's atmosphere. Atmos Meas Tech 6: 2659-2669.

17. Khoshsima M, Ahmadi-Givi F, Bidokhti AA, Sabetghadam S (2014) Impact of meteorological parameters on relation between aerosol optical indices and air pollution in a sub-urban area. Journal of Aerosol Science 68: 46-57.

18. Rashki A, Kaskaoutis DG, Eriksson PG, Rautenbach CJdeW, Flamant C, et al (2013) Spatio-temporal variability of dust aerosols over the Sistan region in Iran based on satellite observation. Nat Hazards 71: 563-585.

19. Gharibzadeh M, Alam KH, Bidokhti AA, Abedini Y, Masoumi A (2016) Radiative Effects and Optical Properties of Aerosol during Two Dust Events in 2013 over Zanjan, Iran. Aerosol and Air Quality Research 17: 888-898.

20. Holben BN, Eck TF, Slutsker I, Tanre D, Buis JP, et al. (1998) AERONET- A federated instrument network and data archive for aerosol characterization. Remote Sensing Environ 66: 1-16.

21. Diner DJ, Beckert JC, Reilly TH, Bruegge CJ, Conel JE, et al. (1998) Multi-angle Imaging Spectroradiometer (MISR) instrument description and experiment overview. IEEE Trans Geosci Remote Sens 36: 1072-108.

22. Kahn R, Li WH, Martonchik J, Bruegge C, Diner D, et al. (2005) MISR lowlight-level calibration and implications for aerosol retrieval over dark water. $\mathrm{J}$ Atmosph Sci 62: 1032-1062.

23. Alam K, Qureshi S, Blaschke T (2011) Monitoring spatio-temporal aerosol patterns over Pakistan based on MODIS, TOMS and MISR satellite data and a HYSPLIT model. Atmospheric Environment 45: 4641-4651.

24. Goudie AS, Middleton NJ (2006) Desert Dust in the Global System.

25. Choobari OA, Ghafarian P, Owlad E (2015) Temporal variations in the frequency and concentration of dust events over Iran based on surface observations. International Journal of Climatology 36: 2050-2062.

26. Gerivani H, Lashkaripour GR, Ghafoor IM, Jalili N (2010) The source of dust storm in Iran: a case study based on geological information and rainfall data. Carpathian J Earth Environ Sci 6: 297-308.

27. Zoljoodi M, Didevarasl A Saadatabadi AR (2013) Dust Events in the Western Parts of Iran and the Relationship with Drought Expansion over the DustSource Areas in Iraq and Syria. Atmospheric and Climate Sciences 3: 321-336.
28. Hamidi M, Kavianpour MR, Shao Y (2013) Synoptic analysis of dust storms in the Middle Est, Asia Pac. J Atmos Sci 49: 279-286.

29. Ranjan RR, Joshi HP, lyer KN (2007) Spectral variation of total column aeroso optical depth over Rajkot: a tropical semi-arid Indian station. Aerosol and Air Quality Research 7: 33-45.

30. Kim HS, Chung YS, Lee SG (2013) Analysis of spatial and seasonal distributions of MODIS aerosol optical properties and ground-based measurements of mass concentrations in the Yellow Sea region in 2009. Environ Monit Assess 185: 369.

31. Xiao N, Shi T, Calder CA, Munroe DK, Berrett C, et al. (2009) Spatial characteristics of the difference between MISR and MODIS aerosol optical depth retrievals over mainland Southeast Asia. Remote Sensing of Environment 113: $1-9$.

32. Prasad AK, Singh S, Chauhan SS, Srivastava MK, Singh RP, et al. (2007) Aerosol radiative forcing over the Indo-Gangetic plains during major dust storms. Atmospheric Environment 41: 6289-6301.

33. Alam K, Trautmann T, Blaschke T, Majid H (2012) Aerosol optical and radiative properties during summer and winter seasons over Lahore and Karachi. Atmos Environ 50: 234-245.

34. Draxler RR, Rolph GD (2003) HYSPLIT (HYbrid Single-Particle Lagrangian Integrated Trajectory) Model access via the NOAA ARL READY Website, NOAA Air Resour. Lab, Silver Spring, MD, USA. Available from: http://www.arl. noaa.gov/ready/hysplit4.html

35. Ramaswamy V, Chen CT (1997) Climate forcing-response relationships for greenhouse and shortwave radiative perturbations. Geophys Res Lett 24 : 667-670.

36. Hansen J, Sato M, Ruedy R (1997) Radiative forcing and climate response. J Geophys Res 102: 6831-6864.

37. Hatzianastassiou N, Matsoukas C, Drakakis E, Stackhouse Jr PW, Koepke P et al. (2007) The direct effect of aerosols on solar radiation based on satellite observations, reanalysis datasets, and spectral aerosol optical properties from Global Aerosol Data Set (GADS). Atmos Chem Phys 7: 2585-2599.

38. Chu D, Kaufman Y, Ichoku C, Remer L, Tanr'e D, et al. (2002) Validation of MODIS aerosol optical depth retrieval over land. Geophysical Research Letters 29: 8007.

39. Remer LA, Kaufman YJ, Tanr'e D, Mattoo S, Chu DA, et al (2005) The MODIS aerosol algorithm, products and validation. Journal of Atmospheric Science 62 : 947-973. 